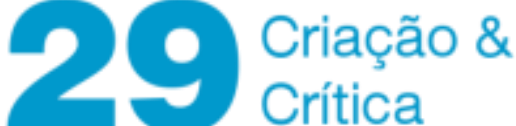

\section{MULHERES NO CINEMA DE HELENA SOlBERG: ENTRE MÚlTIPLOS OLHARES E VOZES, OS DOCUMENTÁRIOS A ENTREVISTA (1966) E THE DOUBLE DAY (1975)}

Meire Oliveira Silva ${ }^{1}$

Resumo: A tentativa de estabelecer uma linha evolutiva em perspectiva comparada na análise das identidades e vivências de mulheres, a partir dos documentários $A$ entrevista (1966) e The double day (1975), de Helena Solberg, é também a tentativa de apreender dois momentos distintos destas obras. Sua autora vivenciou a experiência de olhar e mergulhar na América Latina somente quando fora do Brasil, após o Al-5, e já radicada na capital norte-americana, Washington. No entanto, ao acompanhar a trajetória das trabalhadoras de cidades e vilarejos latino-americanos, em fábricas ou na mineração, ressaltam-se a força e a multiplicidade do sermulher. Sua filmografia então volta-se, definitivamente, para questões sociais que a acompanham até produções recentes, que mantêm as escolhas voltadas às mulheres, talvez, a sua principal temática.

PALAVRAS-CHAVE: Documentários; Helena Solberg; América Latina; Mulheres; Identidades.

\section{WOMEN IN HELENA SOLBERG'S CINEMA: BETWEEN MULTIPLE LOOKS AND VOICES, DOCUMENTARIES A ENTREVISTA (1966) AND THE DOUBLE DAY(1975)}

ABSTRACT: The attempt to establish an evolutionary line in compared perspective in the analysis of the identities and experiences of women, based on the documentaries A entrevista (1966) and The double day (1975), by Helena Solberg, is also the attempt to apprehend two distinct moments from these works. Its author lived the experience of looking and diving in Latin America only when outside of Brazil, after the Al-5, and already living in the North American capital, Washington. However, when following the trajectory of workers in Latin American cities and villages, in factories or in mining, the strength and multiplicity of being-women are emphasized. Her filmography then definitely turns to social issues that accompany her until recent productions, which keep the choices focused on women, perhaps, her main theme.

KEYwORDS: Documentaries; Helena Solberg; Latin America; Women; Identities.

A cineasta carioca Helena Solberg principia sua trajetória cinematográfica ao fazer parte, mesmo que indiretamente, do germinar do Cinema Novo junto a outros realizadores. Assim, foi uma das únicas vozes e presenças femininas naquele meio, ainda nos anos 1960. No entanto, sem se voltar, desde o início, para as classes populares - e empreender uma espécie de conscientização das massas por meio do Cinema -, a realizadora partiria das experiências pessoais ligadas à elite carioca em seu primeiro documentário de curta-metragem, A entrevista (1966). E, somente longe do Brasil,

\footnotetext{
${ }^{1}$ Doutora em Teoria Literária e Literatura Comparada pela Faculdade de Filosofia, Letras e Ciências Humanas da Universidade de São Paulo (FFLCH-USP) e pesquisadora em Teoria e História do Cinema Documentário Brasileiro. E-mail: meire_oliveira@uol.com.br
} 


\section{Criaçäo \&}

autoexilada $^{2}$ nos anos de 1970 em Washington (EUA), ela empreende a "redescoberta", não só de seu país de origem, mas também da própria América Latina. Conhece, finalmente, o continente do qual se viu apartada, de tão distante das orlas cariocas da zona sul, onde cresceu. Descendente de pai europeu, de quem herda o sobrenome, Solberg ponderaria sobre como, nos Estados Unidos, se refeririam a ela, pela primeira vez, como uma mulher latina. E tais questões já apontam para alguns conceitos levantados por Gloria Anzaldúa ao teorizar sobre a própria questão do ser-mulher aliada às incertezas de se colocar frente às exigências de pertencimento a uma nacionalidade:

Nós sabíamos que éramos diferentes, separadas, exiladas do que é considerado "normal", o branco-correto. E à medida que internalizamos este exílio, percebemos a estrangeira dentro de nós e, muito frequentemente, como resultado, nos separamos de nós mesmas e entre nós. Desde então estamos buscando aquele eu, aquele "outro" e umas às outras. E em espirais que se alargam, nunca retornamos para os mesmos lugares de infância onde o exílio aconteceu, primeiro nas nossas famílias, com nossas mães, com nossos pais. A escrita é uma ferramenta para penetrar naquele mistério, mas também nos protege, nos dá um distanciamento, nos ajuda a sobreviver. $E$ aquelas que não sobrevivem? Os restos de nós mesmas: tanta carne jogada aos pés da loucura ou da fé ou do Estado (ANZALDÚA, 2000, p. 232).

Esses fragmentos do feminino irmanam-se ao mal-estar investigado pelas lentes de Helena Solberg, ao afirmar a presença das mulheres no cinema como protagonistas, seja filmando, produzindo ou atuando de modo sempre autoral. Desse modo, corporificam-se, de certa forma, alguns anseios das correntes teóricas feministas em voga na época. Ainda que afastada de suas origens e, por isso mesmo, a elas retornada em uma dialética de contínua descoberta de si mesma - espelhada nas outras mulheres captadas por sua câmera -, a realizadora ancora seu cinema em um olhar estrangeiro, porém voltado às outras existências. Seu protagonismo como autora de filmes documentários a leva a desenvolver uma cinematografia de alteridade que se consagra com as obras seguintes. Diante dela presentificam-se situações erráticas de jovens internas de um reformatório; de trabalhadoras em minas da Bolívia; de operárias nas fábricas argentinas, do México e da Venezuela. Mulheres então identificadas, não mais como distantes, mas estranhamente próximas dadas as existências afirmadas em fissuras identitárias cujos resquícios de colonização permanecem comuns aos países da América Latina.

No seu segundo filme, The emerging woman (1974), Solberg retoma a questão do feminino, já em outra chave. Dá início a uma série de três documentários voltados à problemática enfrentada pelas mulheres em meio às crescentes exigências de imersão no

\footnotetext{
${ }^{2}$ Devido ao ambiente inóspito à classe artística e à intelectualidade brasileiras, após o golpe de 1964, e ao Ato Institucional (Al-5, de 1968), por meio do qual o Estado empreendeu uma série de perseguições a civis em grave aviltamento de seus direitos, no acirramento das exceções e violências impostas pelo regime militar que resultaram em inúmeros mortos, desaparecidos e torturados.
} 


\section{Criaçäo \&}

mercado de trabalho e as visíveis desigualdades de gênero somadas às práticas opressoras de origem colonial. Os dois últimos desta série concluem-se com a imersão da cineasta na América Latina. É este documentário de 1974 que aborda os 170 anos da trajetória feminina nos Estados Unidos da América, sendo o responsável pela condução de Solberg a um cinema militante, independente, ainda que permeado por rigor técnico e pesquisa histórica documental apurada. Por estar afinado com as pautas políticas que, nos anos 1970, explodem naquele país, o documentário obtém aceitação de público e consequente distribuição. Sua veiculação em escolas, universidades e bibliotecas de todos os estados norte-americanos (TAVARES, 2011, p. 29) é significativa para a ampliação de discursos até então muito conciliadores e até homogêneos na abordagem das mulheres, como filme de protesto feminista. Fazendo parte do International Woman's Film Project, um coletivo de cinema realizado por mulheres de diversas nacionalidades, Solberg daria sequência a seu olhar sobre as mulheres de outros países da América, para além de Brasil e Estados Unidos, com The Double Day (A dupla jornada), 1975; e Simplesmente Jenny (1977).

Para este estudo, o recorte cairá sobre as diferentes maneiras de enfocar a constituição feminina em dois momentos da obra da cineasta: entre seu primeiro documentário, de 1966, e o filme de 1975; ao trazerem perspectivas diferentes de olhar, a partir da mulher oriunda das camadas elitizadas da sociedade, cujas preocupações orbitavam em torno de casamento, filhos e como agradar em tarefas domésticas, mas nunca atreladas à subsistência do lar; mantendo sua preocupação com a educação dos filhos, e não com a sobrevivência deles, já que a tarefa estaria, em sua ótica, naturalmente, associada ao marido ou pai. Uma realidade, portanto, muito diferente da maior parte das mulheres na América Latina, e que seria tematizada nos próximos filmes. Essa mudança de perspectiva da cineasta será empreendida juntamente às análises fílmicas para, por fim, averiguar-se as vozes latino-americanas e periféricas emergindo como protagonismos que passariam a representar a tônica dessa obra.

As imagens que Solberg passa a captar desde Argentina, México, Bolívia e Venezuela revelam realidades completamente desiguais. Emergem também os "dois Brasis", os quais Helena Solberg sempre levantará como referências. Eles já germinavam em $A$ dupla jornada em profundo contraste com $A$ entrevista, apesar de ambos mostrarem opressões em diferentes níveis em relação à mulher. A fotografia de Mário Carneiro no filme de 1966, de certa forma, dialoga com as realizações de colegas advindos do Cinema Novo, como Cacá Diegues, Jabor, Saraceni e Glauber Rocha; sobretudo na investigação do cotidiano ordinário de uma moça, mas destoa por voltar-se ao seu casamento como mais uma tarefa de sua iniciação à vida em sociedade. Contudo, as próprias vozes over do relato reforçam essa desconstrução dos ideais do matrimônio como conto de fadas. $\mathrm{E}$, ainda mais, no que se afirma como ausência dos objetivos do Cinema Novo, em níveis sociais e políticos, dada a classe social retratada em seus privilégios e aspirações.

Uma tentativa de reconstrução, talvez, da trajetória do cinema documentário nacional empreenda melhor compreensão da obra da cineasta. Desta maneira, segundo Fernão Ramos (2008), o surgimento do documentário moderno brasileiro data das décadas 1950-60. Focalizando um país não visto até então nas telas - aquele "país de 


\section{Criação \&}

verdade", de miséria, exclusão e desigualdade em suas regiões afastadas, periféricas ou reconditamente localizadas -, constituiria a matéria-prima do chamado Cinema Novo brasileiro. Nesse sentido, Estados Unidos e Canadá, entre as incursões dos Cinemas Direto ou Verdade, inspirá-lo-iam, valendo-se da captação sincrônica entre áudio, imagem - como da apreensão do instante, sem atores -, em situações flagradas por equipamentos mais potentes - e portáteis - essenciais para registrar o real, em tempo real.

Nesse contexto, $A$ entrevista é um documentário que condensa as aspirações de uma geração e de uma sociedade em contínua transformação. E, em fragmentos dessa sociedade frágil em seus valores morais e éticos, o corpo feminino permanece visto como uma consequência das imposições patriarcais. Toda a individualidade feminina virá canalizada à procriação e ao matrimônio, retomando questões afeitas à religiosidade formadora do processo colonizador. Desse modo, aos 6'49" do documentário, a imagem do ventre de uma moça - almejada noiva, juvenil e virginal, portanto, fértil e propícia à perpetuação da célula familiar - na praia, preocupada em ser bela, maquiando-se (mas também lendo porque a cultura fazia parte de seu molde feminino privilegiado socialmente), emergirá. Em suma, formada para desempenhar a função completamente "perfeita" de esposa no sentido convencionalmente advindo de um discurso hegemônico em torno do gênero feminino - enquanto se bronzeia.

A montagem mostra a atriz (Glória Solberg, cunhada da diretora à época) mergulhada em possibilidades do olhar. Entre seus iguais, seres que compartilham das mesmas vivências e angústias próprias dos depoimentos contraditórios - das estudantes da PUC-RJ que aceitaram falar à diretora, já que eram colegas universitárias - entre os desejos e receios, seja na visão do rapaz que joga frescobol até a moça vista de costas se enrolando em uma toalha. No quadro de abertura, existe a premissa de que "Os depoimentos utilizados na narração foram recolhidos entre setenta entrevistas gravadas com moças de 19 a 27 anos de idade, pertencentes a um mesmo grupo social" (A ENTREVISTA, 1966, 12s). Logo, o recorte social é esclarecido como leitmotiv das entrevistas, na análise social de um grupo específico, o da própria diretora, elitizado. $O$ cotidiano de moças - as mesmas universitárias colegas da cineasta - vai sendo exposto à câmera sutilmente, e parece oscilar entre o registro e os exercícios de experimentação fílmica. Já que o jogo entre a essência e a aparência das classes privilegiadas, por meio das imagens das mulheres pilares dessa figuração glamourosa e jovem, é problematizado pela moça sendo maquiada a partir de seus olhos - de uma enigmática Capitu machadiana? - em meio ao depoimento de que a vida sexual da mulher deve ser atrelada ao casamento, e todos os recursos de montagem utilizados.

Os depoimentos tratam da função primordial da mulher nas relações sociais e familiares, como base de uma estrutura, inclusive, econômica, ainda que a consciência dessa colocação não esteja clara em meio às imposições de apagamento de identidades de gênero. A mulher, dessa forma, se recolhe, ao menos nesse segmento social, à exploração de suas potencialidades, como mãe. A força dessas identidades é transformada em figurações de submissão. O excerto de um dos testemunhos parece corroborar com o primeiro depoimento de uma das figuras femininas veiculadas no filme anonimamente: 


\section{Criaçäo \&}

Por isso eu acho que a mulher deve saber línguas, a mulher deve ser socialmente perfeita, para poder no caso seu marido se obrigar dos seus negócios, estar em dia com o que acontece no mundo, ela precisa ler muito, ela precisa ter uma cultura muito grande, mas ela não precisa se dedicar a alguma coisa. Enfim, ela pode encher a vida dela com aulas, com conferências, com uma série de coisas, mas não se dedique a um trabalho (A ENTREVISTA, 1966, 19s, transcrição livre).

Após esse testemunho, a protagonista é mostrada se arrumando em um quarto amplo diante do espelho e mexendo no cabelo, entre gavetas repletas de escovas símbolos associados a um ideal de feminilidade - junto aos frascos de cremes e perfumes com rótulos de marcas estrangeiras dispostos na penteadeira. Marcadores sociais e de gênero estão dispostos por toda a película. Os relatos que seguem ainda oscilam entre o elogio ou as ressalvas das próprias mulheres entrevistadas acerca da educação recebida, destacando-se que "muita liberdade nunca dá em coisa boa", mas também criticando-se a rigidez de uma formação indicada às moças da chamada "elite". Classificação esta, continuamente questionada por elas no enfrentamento dos problemas diários oferecidos pela vida adulta, em todos os depoimentos colhidos. Aliás, aspecto grifado como um dos elementos a ser repensado na educação das filhas das depoentes. A imagem da atriz, depois em trajes de praia, continua a destacar suas belezas e juventude em meio a um closet amplo repleto também de sapatos e acessórios com o detalhe do que parece ser um cofre ao fundo, na ênfase do recorte social.

Uma santa, provavelmente Nossa Senhora de Nazaré, dadas a coroa e a criança que leva ao colo, salta em meio ao quarto por lembrar que aquela juventude está associada à imposição religiosa da maternidade que lhe designa socialmente a função que, por contiguidade, retoma a ideia de uma educação de esmeros destinada à "perfeição". E os breves relatos já propõem o objetivo do documentário, bem como ascendem as questões de classe e gênero, com a posição materna ocupando o primeiro plano da vida feminina. Fazendo uma ponte com a Literatura, brevemente, é imediato perceber que, num misto de ironia e constatação tipicamente conservadora, o escritor Monteiro Lobato já havia descrito, em um de seus contos dos anos 1920, que

Varia a pele, a condição, mas a alma da criança é a mesma - na princesinha e na mendiga. E para ambos é a boneca o supremo enlevo. Dá a natureza dois momentos divinos à vida da mulher: o momento da boneca - preparatório -, e o momento dos filhos - definitivo. Depois disso, está extinta a mulher (LOBATO, 2000, p. 19).

Já a enunciação narrativa do conto Amor, de Clarice Lispector, também dos anos $1960^{3}$, alude a um "destino de mulher" a ser seguido, como o da protagonista Ana,

\footnotetext{
${ }^{3}$ É preciso ressaltar que alguns contos publicados em Laços de família (1960) foram lançados anteriormente em periódicos diversos como a Revista Senhor. Já o conto "Amor" integrou a coletânea Alguns contos (em Os Cadernos de Cultura), em 1952. Logo, faz parte do mesmo período de lançamento da pioneira obra de Simone de Beauvoir, $O$ segundo sexo, que também discute o tal "destino de mulher" a
} 


\section{Criaçäo \&}

cumprindo a sina a ela reservada desde a juventude, "estranha como uma doença de vida", completamente anulada pela fase matrimonial; relacionando-se ao documentário: "Por caminhos tortos, viera a cair num destino de mulher, com a surpresa de nele caber como se o tivesse inventado. $O$ homem com quem casara era um homem verdadeiro, os filhos que tivera eram filhos verdadeiros" (LISPECTOR, 1998, p. 19). A afirmação de que aquela vida findando enfaticamente os dois parágrafos introdutórios do conto clariceano, "Assim ela o quisera e o escolhera" (1998, p. 20-21), contrasta com sua quase satisfação de caber em um destino previamente traçado para ela, no excerto "Ana respirou profundamente e uma grande aceitação deu a seu rosto um ar de mulher" (1998, p. 21). A grande aceitação de outra mulher aparece no curta e naqueles anos 60, como proveniente da classe média moradora da zona sul carioca, em meio a seus afazeres, e projetada na fala de algumas das jovens entrevistadas nesse documentário, poucos anos depois.

Junto a uma fotografia de uma mulher segurando um bebê, aparece o nome de Helena Solberg Ladd, identificada como responsável por argumento, direção e produção no filme. O que se segue são mais fotografias de crianças embaladas por choros, rituais em latim, de algum dos sacramentos cristãos, como casamento ou batismo, e o coro de Parabéns a você, antes de um excerto da fada de Bela Adormecida: "Esqueceram-se de mim, não é? Pois, finalmente, aqui estou eu, bem escondidinha. Vou deixar que as outras fadas façam suas profecias para depois eu fazer a minha" (A ENTREVISTA, 1966, 3min30s). A seguir, imagens de bonecas, crianças pequenas junto a bebês, em festas de aniversário ou ocasiões cotidianas são registradas e coadunam com a montagem dos áudios off. As fotos de turmas de meninas pequeninas ou colegiais junto a freiras parecem arrematar o mote inicial do ciclo do "destino de mulher", anteriormente descrito de contornos bem definidos, que já antecipam a abordagem do curta. Assim como toda a linha religiosa é do mesmo modo confirmada pelas fotos de meninas muito novas em cumprimento de mais sacramentos, como os estudos catequéticos. Enfim, uma vida traçada para atender aos anseios familiares e religiosos.

É preciso destacar que existem marcas distintivas entre os corpos moldados em sociedade desde a mais tenra idade em locais específicos:

As escolas femininas dedicavam intensas e repetidas horas ao treino das habilidades manuais de suas alunas produzindo jovens "prendadas", capazes dos mais delicados e complexos trabalhos de agulha ou de pintura. As marcas da escolarização se inscreviam, assim, nos corpos dos sujeitos. Por vezes isso se fazia de formas tão densas e particulares que permitia - a partir de mínimos traços, de pequenos indícios, de um jeito de andar ou falar - dizer, quase com segurança, que determinada jovem foi normalista, que um rapaz cursou o colégio militar ou que um outro estudou num seminário (LOURO, 2003, p. 66).

partir das imposições de gênero. Observam-se, portanto, neste conto as nuances do feminino a partir dos anos 1950, reverberando-se nas pautas da década de 60. O olhar da escritora sobre o Rio de Janeiro e que, nos anos 1940, vivia fora do Brasil sendo casada com o diplomata Maury Gurgel Valente mostram-se afinados com pautas internacionais dos estudos de gênero. 


\section{Criticãa \&}

Igualmente, seja na versão de Perrault ou dos irmãos Grimm, a figura da Bela Adormecida pode simbolizar o longo período - aparentemente interminável - da quase letargia adolescente que garante a jovens princesas não precisar trabalhar, mas se preparar para a idade adulta que exigirá delas uma postura de enfrentamento de uma vida completamente diferente e impostas a suas existências (BETTELHEIM, 2007, p. 313). Existe também uma associação psicanalítica da maldição da última fada ser, devido à origem bíblica, a menstruação e, na versão dos Grimm da narrativa em questão, a menina fura o dedo na roca de uma máquina operada por uma velha, ou, "de acordo com a Bíblia, a maldição é herdada de mulher para mulher" (BETTELHEIM, 2007, p. 320). Assim, a jovem cai em sono profundo, encerrada em uma torre inatingível com muros de espinhos, e longe dos pretendentes que a deflorariam antes do casamento. Isso é muito explorado ao longo dos séculos e das versões da narrativa, mas é simbólica a sua inserção no filme pelo fato de que traduzem o "despertar de Bela Adormecida, assim como de seu mundo para uma nova vida [...] a encarnação da feminilidade perfeita" (BETTELHEIM, 2007, p. 324).

De acordo com a pesquisadora Mariana Tavares (2011, p. 23), as personagens de Helena Solberg "apresentam um olhar de fora, estrangeiro. É como se essas personagens se sentissem um pouco estrangeiras em suas pátrias". No caso de seu primeiro filme, trata-se de personagens que antecipam as demais que também "estão em processo de transição [...] divididas fragmentadas, cabendo aos filmes a investigação e reconstrução de suas identidades" (TAVARES, 2011, p. 23). Os depoimentos demonstram a fragmentação das personalidades das entrevistadas. Ainda que inseridas em um mesmo espaço social e geográfico, são personalidades imersas em contradições. A questão da cisão do espírito feminino impõe-se às mulheres nas dimensões carnais e espirituais. A inconciliável forma situada entre prazer e ascese afirma-se em depoimentos como "Eu acho que a mulher se inicia sexualmente dentro de um papel passivo. Acontece, ela gosta. Não tem por que resistir, ou tem, mas não resiste e acontece, mas junto de uma entrega afetiva" (A ENTREVISTA, 1966, 10min21s). No entanto, é a formação religiosa que emerge vigorosa em conviç̧ões como "Eu ainda acho que sou bastante conservadora e ainda acho que é melhor que a experiência seja depois do casamento [...] para mim a parte física está muito ligada à parte espiritual" (10min36s). No entanto, outras passagens - "Em geral, todas as coisas existem por vaidade" (11min43s). - em citação bíblica, ao mesmo tempo em que diz gostar muito de liberdade, com a ressalva de uma liberdade que acredita não existir no casamento, mas confessa: "tenho horror de ser dominada por um homem" (12min02s).

Ainda assim, é a formação patriarcal que emerge em afirmações como "Acho que a independência exagerada que a mulher está querendo tomar, não dá certo" ( $A$ ENTREVISTA, 1966, 12min27s). Podem configurar evidências de uma camada social, ainda que privilegiada, envolta em processo alienado de construção identitária. No entanto, tal alienação não inferioriza essas mulheres, mas suscita reflexões que refutam dogmatismos ao ser considerado o documentário como produção inserida em um momento histórico-social determinado. De maneira que o fato de aceitar o papel de 


\section{Criaçäo \&}

mulher dependente de um marido, sob uma mística muito distante das questões levantadas por Betty Friedan (1971), embate-se com justificativas tais como "Porque, inclusive, tem mulheres que se destacam de tal forma que, não digo um complexo de inferioridade, mas enfim, não deixam o homem em uma posição confortável muito de man of the house ou boss of the house"4.

Em uma vida envolta em devaneios pueris acerca do suposto conto de fadas representado pelo casamento redentor, a realidade socioeconômica impõe-se triunfante e desmascara os discursos privilegiados de "Eu acho que se não tivesse casado, estaria eternamente infeliz e insatisfeita comigo mesma. Estaria sempre querendo me casar... porque eu acho que a mulher só é realizada quando se casa". Porque, em sua grande maioria, as mulheres desconhecem tal escolha e são levadas a dividir suas forças de trabalho para cuidar dos filhos e da subsistência familiar. Ao mesmo tempo a imagem da atriz sendo vestida de noiva é justaposta à afirmação de que "a virgindade não significa nada"; seguida por outra de que "a traição causa mais sofrimento ao homem do que à mulher", concluindo a sequência pela relativização de traições físicas e a emocionais que, segundo a depoente, exporiam os desejos recalcados dos indivíduos no âmbito social. A montagem traz então cenas da festa de casamento e da família conduzindo a noiva-personagem ao que seria a próxima etapa de sua vida. E o curta se encerra com a atriz - a única a mostrar seu rosto, já que é casada com o irmão da cineasta e, portanto, "liberada" a exercer suas opiniões em sociedade - confessando para a câmera que aprendeu a conviver com suas incoerências e ambiguidades, desde muito nova, sem idealizar o casamento. A cena de arremate do filme mostra um cinejornal da Marcha da Família com Deus pela Liberdade, e o golpe no presidente João Goulart, com a narração off.

Apoiada pelas entidades femininas, MAF (Movimento de Arregimentação Feminina) e CAMDE (Campanha da Mulher pela Democracia), realizou-se em março de 1964 a Marcha da Família com Deus pela Liberdade, movimento esse que se propunha a preservar a democracia. Com a deposição de João Goulart, a 1ํ de abril de 1964, implantou-se no Brasil um novo governo (A ENTREVISTA, 1966, 17min12s).

É preciso enfatizar o silenciamento estabelecido no filme em consonância com a própria censura e os incessantes movimentos de repressão contra qualquer levante dirigido ao regime militar. Esse término abrupto e, aparentemente, deslocado dialoga com o cerceamento cada vez mais imposto às artes brasileiras a partir do golpe de 1964. Ao mesmo tempo, ponderar sobre afirmações como "Eu acho que a política destrói o homem. É um negócio muito construído e eu, num certo sentido, sou muito idealista, muito mais pura..." poderia provocar a compreensão de que essas mulheres, apesar da ausência de um discurso despojado de engajamento social ou emancipação, de fato, acreditavam no que diziam ou tinham receio de se expor, mesmo que sem seus rostos, em testemunhos,

\footnotetext{
${ }^{4}$ Conforme um dos depoimentos do documentário A entrevista (1966).
} 


\section{Criaçäo \&}

para a entrevistadora? A grande marca desta obra na filmografia brasileira talvez resida no fato de que essa proposta temática toca em pontos como casamento, sexualidade e emancipação, como tão caros às mulheres daquela geração, e bastante inéditos e ousados, pois não havia nada parecido naquele Brasil em suas expressões artísticas. De fato, em 1966, não havia outros filmes ou produções que versassem sobre tais temáticas. Helena Solberg comenta sua primeira realização fílmica:

Aí eu fiz o meu primeiro filme, chamado $A$ entrevista, e que já tem um pouco essa mistura minha que eu acho interessante, e que não era uma coisa totalmente consciente, que é essa coisa de documentário e ficção misturados. Eu saí entrevistando moças da PUC, de formação burguesa como eu, sobre casamento, sexo, política. Eu andava com um Nagra pendurado no ombro, fazendo um áudio, e com esse áudio eu criei uma imagem meio que mítica sobre a mulher se preparando para o casamento. Mário Carneiro foi quem fotografou, é lindíssima a fotografia. É um filme em preto e branco de uma moça sendo vestida como em um ritual para o casamento, e, ao mesmo tempo, essas entrevistas meio que desmistificam aquela imagem, vão fazendo e costurando um comentário sobre aquilo (MULHERES DO CINEMA BRASILEIRO, 2005).

Talvez essa autoanálise a tenha levado a mudar o rumo de seu cinema e, o fato de observar o Brasil de fora parece ter-lhe permitido mudar as perspectivas em relação às questões sociais, sobretudo ao se reconhecer como uma mulher latina. Mesmo com traços considerados fenotipicamente brancos para o país:

Como mujeres tercermundistas, estamos especialmente vulnerables al demónio de muchas cabezas de la opresión. Somos las mujeres que estamos más abajo. Muy pocas opresiones pasan sobre nosotras sin tocarnos. Trabajar hacia la libertad de nuestra piel y nuestra alma quiere decir, como la Colectiva Río Combahee declara, "todos los demás tendrían que ser libres ya que nuestra libertad exigiría la destrucción de todos los sistemas de la opresión". El amor que tenemos por nuestros cuerpos denigrados y almas em común tiene que florecer en lucha. Tenemos que trabajar para diminuir la posibilidad de ser encerradas em una celda rellenada, de ser golpeadas, o asaltadas sexualmente. [...] La visión del feminismo radical tercermundista hace como una necesidad nuestro empeño em trabajar con esa gente que se siente cómoda em el mundo zurdo - los marginalizados de este mundo: los de color, los jotos, los pobres, la hembra, los incapacitados. De nuestra conexión de sangre y espíritu con estos grupos, nosotras mujeres de abajo a través del mundo podemos formar un feminismo internacional" (CASTILLO; MORAGA, 1988, p. 2$)^{5}$.

\footnotetext{
5 "Como mulheres do Terceiro Mundo, somos especialmente vulneráveis ao demônio multifacetado da opressão. Nós somos mulheres situadas mais abaixo. Bem poucas opressões passam por nós sem nos tocar. Trabalhar pela liberdade de nossa pele e de nossa alma significa, como declara o Coletivo Rio
} 


\section{Criaçäo \&}

A partir dos anos 1970, Helena Solberg vê-se impelida a intensificar sua participação efetivamente política nas pautas feministas aludidas por seu cinema realizado fora do Brasil. Em relação a essa preocupação, sua perspectiva distanciada, mas ainda atrelada ao Rio de Janeiro, de formação patriarcal, escravocrata e colonial, é acirrada pelas análises de como se dão as opressões ligadas ao sistema capitalista nas relações entre Estados Unidos e a América Latina. Isso se dá por meio do acompanhamento da vida das mulheres nas áreas rurais e nas fábricas, de modelos econômicos vinculados às ditaduras que vigoraram nos países latino-americanos junto à colonização que moldou a formação de suas histórias. Aproxima-se então desses modelos econômicos de produção cuja força de trabalho feminina é um novo meio de exploração e dominação.

The double day, em seus 56 minutos, é iniciado pela reflexão acerca do desemprego na América Latina e a segregação de gênero empenhada diante desse contexto social. Desse modo, abre-se com as mulheres falando sobre a dificuldade de conseguir trabalho nas fábricas (de Argentina, Venezuela e México, países enfocados no filme), ou até conseguindo alguma colocação mediante salários irrisórios. Assim, são ainda mais expostas à exploração em dupla jornada de mulher operária, mãe e dona de casa. Todavia, justamente por questões de gênero envolvendo o fato de "engravidar e menstruar", como aparece na fala de um dos depoentes - um funcionário com cargo de chefia -, "justificam-se" as razões dessa desigualdade entre as operárias e os operários.

Outro homem entrevistado reforça o depoimento anterior dizendo que "o problema dela não sei qual é, mas trabalhos existem". Ignora-se novamente a condição das mulheres candidatas a empregos como domésticas e as péssimas condições oferecidas. Assim como também são julgadas e ignoradas as situações das trabalhadoras das minas da Bolívia. Uma delas conclui: "Sendo mulher, a mulher serve ao homem e nada mais." Os "milagres econômicos" latino-americanos reforçam a precarização da vida dos mais pobres. O que fica claro ao se destacar a posição do Brasil, por exemplo, nos anos 1970, na política social e econômica dos "anos de chumbo". Refletia-se, desse modo, a situação da América Latina de muitas maneiras, ao contar com uma economia de ordem colonial, erigida por meio de mão-de-obra escrava, cuja exploração acirrada pelo patrimonialismo e a grande exportação de matéria-prima, contribuiu para que fosse perpetuada a inferiorização, sobretudo das mulheres, até a atualidade. De fato, ainda hoje as mulheres não conseguiram alcançar plenamente os direitos trabalhistas ou o acesso à educação formal.

Combahee, "todos os demais deveriam ser livres, pois nossa liberdade exigiria a destruição de todos os sistemas de opressão". O amor que temos em comum por nossos corpos e almas denegridos tem que florescer na luta. Temos que trabalhar para diminuir a chance de sermos aprisionadas em uma cela lotada, espancadas ou sexualmente abusadas. [...] A visão do feminismo radical do terceiro mundo faz nosso esforço para trabalhar com aquelas pessoas que se sentem confortáveis no mundo canhestro como uma necessidade - os marginalizados deste mundo: os negros, os homossexuais, os pobres, o feminino, os deficientes. A partir de nossa conexão de sangue e espírito com esses grupos, nós, mulheres subalternizadas, em todo o mundo, podemos formar um feminismo internacional" (CASTILLO; MORAGA, 1988, p. 2, tradução livre). 


\section{Criaçäo \&}

É preciso destacar o próprio emprego da trabalhadora doméstica, visto ainda na sociedade brasileira, como uma extensão dos serviços desempenhados pelas mucamas escravizadas. Disso decorre a relutância em evitar a oficialização e consequente valorização de suas atividades profissionais e seus direitos trabalhistas, sobretudo pela elite empregadora. O pátrio poder, assegurado pelo Código Civil Brasileiro de 1916, vigente na ocasião, asseverava a inferiorização das mulheres diante do modelo masculino definindo o marido como o líder da sociedade conjugal. Modelo, aliás, endossado pelas mulheres da elite brasileira presente em $A$ entrevista (1966). No caso da Argentina, as políticas educacionais reservadas às mulheres até demonstraram certo avanço em relação aos outros países abordados no documentário.

Já as mulheres bolivianas de polleras e chapéus à moda inglesa, em caracterização típica aymaras, não são aceitas para os trabalhos nas minas devido às vestimentas. Precisam, então, trabalhar em fábricas de costura, geralmente sem vagas e em condições precárias que deflagram preconceitos de gênero e étnico. Há outras que trabalham nas minas em substituição aos maridos que costumam morrer muito jovens devido à insalubridade de suas funções. Essa condição, comum na América Latina era compartilhada em África e Ásia, devido às atividades colonizadoras exploratórias de minérios preciosos. O caso da Bolívia, da busca pelo "El Dorado", pode ser um dos símbolos mais emblemáticos.

Entre as fábricas de costura e as minas de extração de riquezas desde os primórdios, a história se repete avassaladora. Em The double day, as meninas não querem estudar porque não veem perspectiva de futuro por meio dos livros. Além de haver também a prerrogativa de que não se costumava contratar mulheres que tinham filhos. Já os meninos, como seus pais, não respeitam as autoridades das mães sobre eles. E, após a morte do "chefe da casa", repetem o mesmo procedimento de subjugar as mães e demais mulheres da família. A mulher-mãe nutre o novo operário para a mulheresposa cuidar do pai operário e gerar novo filho, futuro operário, em outro ciclo.

Apesar de convencionalmente ser uma atividade própria dos homens, devido à resistência física e à conformação biológica mais adaptada a cargos cujos esforços dispendam grande força física, as mulheres mineradoras na Bolívia somam-se àquelas que conseguem exercer tais atividades e ainda desempenhar as atividades domésticas das quais filhos e maridos são dependentes. No caso da viuvez, não raro segundo os depoimentos presentes no documentário em questão, a responsabilidade recai sobre a mulher cobrando-lhe performances de "provedora e parideira".

E a exploração da força de trabalho dessas mulheres está submetida não só aos seus superiores, mas também aos demais homens trabalhadores que supostamente seriam subalternos nesse processo. A questão de gênero emerge. Até nas fábricas argentinas as mulheres dizem trabalhar mais do que os homens que apenas terminam o que elas começaram. Pronunciamento típico ressaltando a responsabilidade e a imaturidade, respectivamente, de mulheres e homens, para justificar a carga de trabalho exaustivo a elas destinada. Até funções que exigem menos esforço físico, como a de datilógrafas, contadoras, telefonistas, secretárias e funções administrativas em geral, muitas mulheres são preteridas por diversas questões de entrelaçamentos opressivos e 


\section{Criaçäo \&}

excludentes relativos às origens de gênero, sociais e étnico-raciais, entre outras. Como demonstra uma das entrevistadas que parece ocupar cargo de gerência com a usual justificativa: "Mulheres engravidam e menstruam". O documentário parece atestar que, enquanto a mulher se ativer a um papel secundário, a luta operária estará reduzida à metade e o sistema continuará a se alimentar dessas imposições, como uma das mulheres levanta em meio a outras em um coletivo.

Assim, The double day aborda não a conquista do voto feminino - chamariz da chamada "primeira onda" feminista - ou conquista de exercer trabalhos extradomésticos , mas a opressão imposta às mulheres, a invisibilidade de suas funções trabalhistas e também a impossibilidade de exercer sua cidadania por meios democráticos. Ao partir da força de trabalho das mulheres como fator expressivo, suscita a reflexão de uma potência silenciosa e largamente usurpada, sobretudo nos continentes colonizados entre as diversas estratégias de dominação, que sempre enxergou os corpos femininos como secundários e descartáveis. A notoriedade desse elemento de desigualdade é até visto como natural ou mera consequência entre as mulheres pertencentes às camadas sociais menos favorecidas, mesmo que os levantes femininos na Bolívia, Argentina ou no México estejam sendo engendrados a partir das pequenas comunidades rurais ou entre as trabalhadoras das fábricas no espaço urbano.

A ideia de lideranças femininas atuarem em sociedade, nos bairros, escolas, agrupamentos populares diversos, é um fenômeno que instiga a curiosidade por seu caráter de afronta e resistência contra as forças dominantes, ainda colonizadora de mentes e corpos. Considerando-se o gênero feminino como uma construção social que o relega ao apagamento e à opressão, percebe-se o enraizamento de pautas religiosas que tentam legitimar violências reguladoras da concepção somente anatômica e biológica de homens e mulheres. O conceito, apesar de óbvio e até ultrapassado dado o simplismo de sua explicação, ainda é o mote norteador das falas do documentário, como o será também nos discursos hegemônicos sobre as mulheres. As relações históricas e sociais se impõem determinantes nesse processo.

A diretora buscou registrar as diferentes reivindicações femininas tentando abarcar sua pluralidade. The double day realiza um cinema documentário muito mais voltado ao gênero jornalístico cujas reportagens investigativas constituíam a estética a formar uma autoria muito pronunciada de Solberg, ao exercer o papel de uma observadora de seus entrevistados e dos contextos que os envolviam. Nesse projeto, a questão feminina estava afirmada primeiramente na equipe só de mulheres, com exceção do diretor de fotografia Affonso Beato, um dos principais nomes do cinema brasileiro dos anos 1970; fotógrafo cujas raízes foram plantadas ainda no Cinema Novo. Nessa busca pela confirmação do papel feminino como identidade profissional, as inspirações calcadas no Cinema Direto norte-americano também contribuíram para a formação da cineasta. $\mathrm{E}$, ao voltar-se para as pautas do feminino invisibilizado, por meio da realidade das mulheres submetidas ao sistema capitalista da América do Sul, entre as áreas urbanas e rurais. Sobre esse espaço de difícil reconhecimento, explica María Lugones: 


\section{Criaçäo \&}

Entiendo la indiferencia a la violencia contra la mujer en nuestras comunidades como una indiferencia hacia transformaciones sociales profundas en las estructuras comunales y por lo tanto totalmente relevantes al rechazo de la imposición colonial. Busco entender la forma en que se construye esta indiferencia para, así, convertirla en algo cuyo reconocimiento sea ineludible para quienes sostienes que están involucrados en luchas liberadoras. Esta indiferencia es insidiosa porque impone barreras impasables en nuestras luchas como mujeres de color por nuestra propia integridad, autodeterminación, la médula misma de las luchas por la liberación de nuestras comunidades. Esta indiferencia se halla tanto al nivel de la vida como al nivel de teorizar la opresión y la liberación. La indiferencia no está provocada solamente por la separación categorial de raza, género, clase y sexualidade, separación que no nos deja ver la violencia claramente. No se trata solamente de una cuestión de ceguera epistemológica cuyo origen se radica en una separación categorial (LUGONES, 2008, p. 4) ${ }^{6}$.

Já Glória Martín, a cantora venezuelana autora de Mujer ${ }^{7}$, canção emblemática da banda sonora do documentário, destacou-se em seu ativismo na música. Em forma de poema de protesto, essa letra é uma das representantes da Nueva Canción Latinoamericana que, entre as décadas de 1960 e 1970, fez uma frente de resistência, substituindo os confrontos diretos utilizados em manifestações até então, sobretudo na Venezuela. Assim, a música que encerra o documentário é repleta de versos que descrevem as lutas por equidade em prol das vozes das mulheres. Há barreiras impostas historicamente aos gêneros: "...de ti van a decir cosas muy feas cuando no quieran ser incubadoras, dirán, no sirven estas mujeres ahora" ${ }^{8}$, apesar do fato de que a força das mulheres em avanço coletivo demonstra-se pela enumeração dos substantivos que apontam para a certeza de que, para além das categorizações, as conquistas e a expressão de seus anseios já demarca o enfrentamento das forças acirradas pelas investidas imperialistas a subjugar os corpos femininos ainda vistos como colonizados em

\footnotetext{
6 "Entendo a indiferença à violência contra as mulheres em nossas comunidades como uma indiferença às profundas transformações sociais nas estruturas comuns e, portanto, totalmente relevante para a rejeição da imposição colonial. Procuro compreender a forma como essa indiferença se constrói para transformá-la em algo cujo reconhecimento é inevitável para aqueles que afirmam estar envolvidos em lutas libertadoras. Essa indiferença é insidiosa porque impõe barreiras intransponíveis em nossas lutas como mulheres de cor por nossa própria integridade, autodeterminação, o próprio cerne das lutas pela libertação de nossas comunidades. Essa indiferença é encontrada tanto no nível da vida quanto no nível da opressão e da libertação de teorias. A indiferença não é causada apenas pela separação categórica de raça, gênero, classe e sexualidade, separação que não nos permite ver com clareza a violência. Não se trata apenas de cegueira epistemológica, cuja origem está em uma separação categórica" (LUGONES, 2008, p. 4, tradução livre).

7 "Mujer si te han crecido las ideas/de ti van a decir cosas muy feas/que no eres buena [...]/que cuando callas te ves mucho más hermosa./[...] Mujer, semilla, fruto, flor, camino [...]" cuja tradução livre é "Mulher se cresceram em ti as ideias/de ti dirão coisas muito feias/ que não és boa [....]/que quando te calas parece muito mais bonita/[...] Mulher, semente, fruto, flor, caminho [...]".

8 “... de ti dirão coisas muito feias quando não quiseres ser incubadora, dirão, agora não servem essas mulheres..." (tradução livre).
} 


\section{Criaçäo \&}

todos os sentidos, como nas expressões "Mujer, semilla, fruto, flor, camino, pensar es altamente femenino"'.

A letra também alude à falta de acesso à educação e aos empregos dignos, já que a situação de meninas e jovens, tanto das áreas rurais quanto urbanas, está pautada por suas forças de trabalho, impondo-lhes inevitável desmotivação para seguirem nos estudos. Isso se deve também ao objetivo longínquo de ingresso nas universidades, seja para jovens egressos de áreas rurais ou em situações de vulnerabilidade socioeconômica. Tal limitação de acesso à educação superior está relacionada principalmente com a falta de perspectivas empregatícias ou restrições relacionadas aos "trabalhos de mulher". O documentário The Double Day, em suma, examina a opressão das mulheres em países subdesenvolvidos como uma imposição econômica que acirra as violências de gênero. Esse dado intensifica-se através da História e, no filme, apresenta-se simbolizado, entre mulheres casadas - e donas de casa - com mineradores bolivianos, operárias argentinas (empregadas domésticas, sobretudo) e mexicanas, além das ativistas venezuelanas em reuniões políticas a refletir sobre as questões limitadoras das atividades femininas na militância em contraste com a condição de mães, esposas e principais responsáveis pelos afazeres domésticos.

Muitas das queixas versam em torno da viuvez e do desamparo do Estado pelas famílias que perdem a única renda familiar, sobretudo, nas atividades insalubres nas minas da Bolívia. Jovens grávidas e jovens viúvas irmanadas no mesmo destino de opressão. Mesmo nas capitais Buenos Aires, Caracas e La Paz, a situação não era diferente dos vilarejos interioranos e a semelhança superava as dimensões geográficas. E as observações da voz over realizam estudo sociológico acerca da realidade, algo tipicamente tratado pelos documentários dos anos 1970. No documentário, a distinção entre homens e mulheres para justificar a opressão da mulher no ambiente de trabalho por sua "delicadeza e precisão", ao contrário das tarefas que requerem força física, é corroborada pelos depoimentos de dirigentes na fábrica à cineasta ao mesmo tempo em que os locais - e filas - destinados a meninos e meninas em uma escola primária não são coerentemente explicados pelo homem responsável pela organização na escola em questão.

E como a posição política e consciente sobre a imagem da mulher latinoamericana havia sido ressaltada, o documentário estreou na Primeira Conferência Internacional da Mulher, no México (1975). E o filme toca, inclusive, em questões que já problematizam as aspirações contidas no livro Mística feminina (FRIEDAN, 1971) com um dos depoimentos de uma mulher loira de meia idade que considera a vaidade feminina como a responsável pelo sucesso dos matrimônios, desconsiderando toda a luta feminina secular por dignidade e equidade nas relações sociais, ao afirmar: "Penso que as mulheres teriam menos conflitos e mais sucesso se pudessem parecer mais atraentes aos homens e utilizar as armas femininas" (THE DOUBLE day, 1975, 29 min., tradução e

\footnotetext{
9 “Mulher, semente fruto, caminho, pensar é altamente feminino" (tradução livre).
} 


\section{Criação \&}

transcrição livres $)^{10}$. Assim, lança-se luz sobre as questões interseccionais de opressão vividas pelas mulheres em sociedades periféricas como os países onde a desigualdade e a opressão oriundas de suas raízes coloniais são flagrantes.

Pelos traços físicos, vestimentas e "preocupações", aquela mulher que se coloca diante da câmera é uma mulher que não pertence às classes populares das entrevistadas anteriormente e representa somente um extrato ínfimo dessas populações registradas durante o filme. Também não representa as batalhas diárias da mulher operária ou da trabalhadora que se desdobra em diversas jornadas - para além da dupla sugerida pelo título - em condições que ultrapassam as pautas trabalhistas em ambientes adequados. Uma das mulheres - Domitila Barrios de Chungara - líder de trabalhadoras domésticas de uma comunidade boliviana é o contraponto que representa toda a condição das mulheres latino-americanas ao ponto de narrar um massacre executado por tropas do exército a protestos de famílias por direitos trabalhistas nas atividades mineradoras. Segundo Aimé Césaire,

Provam que a colonização desumaniza, repito, mesmo o homem mais civilizado; que a acção colonial, a empresa colonial, a conquista colonial, fundada sobre o desprezo pelo homem indígena e justificada por esse desprezo, tende, inevitavelmente, a modificar quem a empreende; que o colonizador, para se dar boa consciência se habitua a ver no outro o animal, e se exercita a tratá-lo como animal, tende objectivamente a transformar-se, ele próprio, em animal. É esta acção, este ricochete de colonização, que importava assinalar. [...] Entre colonizador e colonizado, só há lugar para o trabalho forçado, a intimidação, a pressão, a polícia, o imposto, o roubo, a violação, as culturas obrigatórias, o desprezo, a desconfiança, a arrogância, a suficiência, a grosseria, as elites descerebradas, as massas aviltadas. Nenhum contacto humano, mas relações de dominação e de submissão que transformam o homem colonizador em criado, ajudante, comitre, chicote e o homem indígena em instrumento de produção. É minha vez de enunciar uma equação: colonização = coisificação (CÉSAIRE, 1978, pp. 23-25).

A lógica da dominação é explicada, por exemplo, ao serem enumerados os exemplos da cultura brasileira, para justificar os estereótipos em relação à força e à malandragem do homem nativo e a sensualidade da nativa, ambos se valendo da condição tida como malandra e vantajosa por adaptação para condicionar as investidas de uma força opressora, segundo algumas das ponderações da antropóloga Lélia González (1998). Assim como a violência colonial voltada à desumanização (FANON, 1968, p. 40) é largamente explorada por autores que se situam fora do eixo hegemonicamente utilizado para explicar a condição das civilizações erigidas sob o colonialismo.

\footnotetext{
10 "Creo que las mujeres tendrían menos conflictos y más éxito si pudieran verse más atractivas para los hombres y usar armas femeninas" (THE DOUBLE day, 1975, 29 min., transcrição livre do áudio original em espanhol).
} 


\section{Criaçäo \&}

Essa indignação por ter se juntado a outras vozes e acusada, por isso, de subversão, ressoa como um grito abafado por séculos. A imagem final do documentário serve para arremate na canção Mujer, anteriormente citada. E as demais canções utilizadas na trilha, logo em seu início, trazem a demarcação sobre a exploração espanhola dos minerais na América Latina. $E$ as práticas coloniais em muito se mantêm nas ex-colônias integrando-se às práticas econômicas que perduram nessas sociedades para a movimentação de riquezas ainda pautada por uma lógica exploratória:

A ação colonizadora reinstaura e dialetiza as três ordens: do cultivo, do culto e da cultura. A ordem do cultivo, em primeiro lugar. As migrações e o povoamento reforçam o princípio básico do domínio sobre a natureza, peculiar a todas as sociedades humanas. Novas terras, novos bens abremse à cobiça dos invasores. Reaviva-se o ímpeto predatório e mercantil que leva à aceleração econômica da matriz em termos de uma acumulação de riquezas em geral rápida e grávida de consequências para o sistema de trocas internacional. Pode-se calcular o que significou para a burguesia europeia, em pleno mercantilismo, a maciça exploração açucareira e mineira na América Latina. Se o aumento na circulação de mercadorias se traduz em progresso não resta dúvida de que a colonização do Novo Mundo atuou como um agente modernizador da rede comercial europeia durante os séculos XVI, XVII e XVIII (BOSI, 2006, p. 20).

Essa colonização perpetuada é enfrentada de modo consciente por muitas das mulheres entrevistadas, juntamente aos demais mecanismos de controle daí decorrentes. Mostra-se, por exemplo, uma reunião de mulheres jovens, algumas delas mães com crianças. Suas queixas relacionam-se ao papel político da mulher limitado nas comunidades devido às imposições de suas obrigações domésticas entre o casamento e a maternidade. A ditadura argentina, entre 1976 e 1983, de enormes proporções ao ser considerado o número de exilados, desaparecidos e perseguidos políticos, contou com significativa organização de mulheres unidas na defesa de seus familiares. Foram elas também que se responsabilizaram por assumir os papéis de liderança nos lares ou no espaço público, como a trajetória das Mães da Praça de Maio. Nesse momento, o movimento feminista foi renovado e se impôs epistemologicamente, impulsionado pela segunda onda cujas posições incitavam transformações, a partir dos Estados Unidos e Europa. O caso específico da Argentina esteve envolto em pautas institucionalizadas diretamente atreladas à ditadura:

O exemplo mais representativo é a lei da guarda compartilhada (lei $\mathrm{n}$. 23.264/1985). O Código Civil de Velez Sarsfield havia permanecido inalterado, ordenando a primazia do pai em relação à tutela dos filhos, constituindo uma clara exposição do déficit dos direitos civis das mulheres. $\mathrm{Na}$ ditadura, durante as saídas de urgência para o exílio, não foram poucas as que tiveram de enfrentar a dificuldade quase intransponível de não poder tirar seus filhos menores de idade do país depois que seus 


\section{Criaçäo \&}

companheiros haviam sido levados pelas forças repressivas (ARCHENTI; BARRANCOS, 2017, p. 58).

O imperativo de limitar a ocupação de lugares sociais em categorias que opõem homens e mulheres em suas constituições biológicas, oprime os seres, ao definir o papel das mulheres como apenas doméstico e dos homens como provedores. Deste modo, as relações de poder enraízam-se na sociedade normalizando a assimetria dessas ações e identidades.

Do ponto de vista histórico e social, a figura da mulher está ancorada em uma resistência às diversas opressões estruturais decorrentes de um patriarcado de raiz colonial, mas que subsiste em relação aos inusitados diálogos construídos por meio de vivências múltiplas concernentes à questão de interseccionalidade que perpassa toda a história das mulheres latino-americanas como construto antropológico. Qualquer interpretação que não se interponha aos discursos hegemônicos também não se aterá à singularidade de cada nação latino-americana, já que todas essas civilizações foram especificamente atingidas pela colonização e suas consequências inevitáveis.

Um novo paradoxo aparece então. De modo geral, o nacionalismo, para afirmar-se, rejeita o outro e acaba por tender ao racismo. Um nacionalismo que reconhece e exalta a mestiçagem defronta-se com o problema da definição dos limites na acolhida da alteridade. A mestiçagem, como ideologia, apresentou-se frequentemente como racismo disfarçado. No fim do século XIX, certos pensadores latino-americanos encararam a mestiçagem como possibilidade de branqueamento e melhoria da raça. No Brasil, a aliança do branco com o índio, idealizada porque remota, era mais facilmente admitida do que a aliança com o negro, demasiadamente presente e visivelmente outro. No século XX, sobretudo depois da obra de Gilberto Freyre, Casa grande e senzala (1933), a situação inverteu-se e os intelectuais passaram a declarar suas origens negras. Essa assunção lhes dava boa consciência, e os marcava como verdadeiros brasileiros, diversos dos novos imigrantes europeus ou orientais. No afã da busca de uma identidade totalmente liberada da Europa, alguns intelectuais inverteram o sinal e chegaram a um racismo antibranco, declarando, por exemplo, que Argentina e Uruguai eram demasiadamente europeus para serem considerados América Latina. Foi o caso de Darcy Ribeiro, em um momento pouco feliz (PERRONE-MOISÉS, 1997, p. 234).

Pensando nessas multiplicidades identitárias, pode-se entrever a "escrita fílmica" de Helena Solberg, a partir de sua própria realidade e enfocar um estrato social que ilustraria o peso de ser privilegiado socialmente em sociedades tão desiguais. Portanto, ao serem comparadas as duas fases da cineasta por meio de seu primeiro filme e de outro já realizado fora do país em coletividade afirmando o protagonismo feminino no cinema, é possível perceber que sua identidade ultrapassou a questão da nacionalidade ao descolonizar uma prática comumente aplicada ao gênero e à origem étnica. A vivência 
de uma imposição capitalista submete corpos e identidades a normas pautadas pelo heteronormativismo, para além de uma apreensão subjetiva e histórica de elementos opressores. As narrativas são múltiplas e as ações de compreensão precisam se adaptar às necessidades de um novo olhar para as existências, poupando a mulher de uma opressão ancestral apenas por conveniência social na reprodução de performances inconscientemente impostas aos sujeitos.

Sendo assim, nas entrelinhas dos depoimentos do primeiro curta-metragem, pode-se perceber que, mesmo soando conservadoras, as mulheres da alta sociedade carioca viam no matrimônio um papel-chave para atuação em sociedade, na perpetuação da família. Assim, havia, de certa forma, uma ideia de dignidade e de completude entre os gêneros em suas falas, deslocadas pela formação educacional, religiosa e familiar, ao relegar a mulher a uma função reprodutora. De certo modo, aquelas depoentes cariocas reivindicavam um protagonismo junto ao homem para unir forças complementares de modo a formar uma sociedade cuja fortaleza estaria na família. Se os intuitos eram, inconscientemente, os mesmos, os entendimentos desses anseios soavam díspares, justamente, pela falta de compreensão das inúmeras expressões e existências das mulheres.

Reconhecer-se como membro de uma nação tende a significar uma espécie de convenção reelaborada continuamente na História, dado que nada é definitivo ou inegociável, mas revogável na trajetória escolhida pelos indivíduos. A pedagogia decolonial, portanto, seria a ciência que não é concebida convencionalmente, já que existe uma centralidade no conhecimento válido considerando o mundo eurocêntrico e estadunidense. A disputa pelo poder e pelo caráter epistêmico nos estudos acadêmicos desafiam a validação de conhecimentos produzidos fora desses eixos. Na proposição de abertura para outros saberes e epistemologias, há uma busca por descentralização desse poder pelo conhecimento. As cartas dos descobrimentos, por exemplo, giram em torno do que são as pessoas e seres avistados nas Américas. Processo de determinação racial entre colonização e dependência. Há uma categorização biológica do poder. A raça pauta outras marcações de diferenças, como a de gênero. A diferença de gênero pauta as diferenças entre as mulheres negras e brancas. A modernidade está fundada na ideia de raça para a colonialidade. É preciso perceber como as culturas silenciadas produzem epistemes, em seus processos sociais, como memórias e narrativas. Como as populações tinham língua e escritas irreconhecíveis aos colonizadores, para esta perspectiva, o racismo foi organizador dessas relações de poder daí oriundas. E, assim como as relações de poder sofrem mutações, perpetuamse exclusões sobretudo às mulheres.

A decolonialidade, portanto, permite agregar saberes que estão no mundo, mas de forma silenciada, já que a modernidade está fundada na desigualdade de raças, gêneros e culturas. Lélia González (1988) destaca o caráter dos feminismos que desconsideram os discursos que não são brancos. Frantz Fanon (1968) propõe alternativas que possam ressaltar as vozes dos povos colonizados através de um discurso próprio, e não erigido por um olhar apartado dessas vivências. Seria preciso superar a modernidade e o capitalismo para evitar epistemicídios que desconsideram 


\section{$29 \cos _{\text {Criticăa \& }}^{\text {Crãa }}$}

existências e saberes diversos ou transformar olhares e sensibilidades rumo ao reconhecimento de alteridades. Nesse sentido, a obra de Helena Solberg trilha tais caminhos desde os anos 1970, ao questionar seu lugar de privilégio para pensar e produzir cinema - sua escrita de si mesma e do Outro - no Brasil e em outros países latino-americanos.

\section{Referências Bibliográficas}

A ENTREVISTA. Direção: Helena Solberg. Brasil, 1966, p\&b, 19 min. ANZALDÚA, Gloria. "Falando em línguas: uma carta para as mulheres escritoras do terceiro mundo". Estudos feministas, Florianópolis, ano 8, 2000.

BARRANCOS, D; ARCHENTI, N. "Feminismos e direitos das mulheres na Argentina: história e situação atual." In: BLAY, E.; AVELAR, L. (Org.). 50 anos de feminismo: Argentina, Brasil e Chile. São Paulo: Edusp, 2017.

BETTELHEIM, Bruno. A psicanálise dos contos de fadas. São Paulo: Paz e Terra, 2007. BOSI, Alfredo. Dialética da colonização. São Paulo: Companhia das Letras, 2006.

CASTILLO, Ana. MORAGA, Cherríe (Org). Esta puente, mi espalda: voces de mujeres tercermundistas en los Estados Unidos. São Francisco: Ism Press, 1988.

CÉSAIRE, Aimé. Discurso sobre o colonialismo. Lisboa: Livraria Sá da Costa, 1978.

CINECLUBE DELAS. Retrospectiva Helena Solberg: debate sobre os documentários $A$

Entrevista e A Nova Mulher. Disponível em:

https://cineclubedelas.wordpress.com/2018/03/13/retrospectiva-helena-solberg-debatesobre-a-entrevista-e-a-nova-mulher/ Acesso em: 16.04.2020.

FANON, Frantz. Os condenados da terra. Rio de Janeiro: Civilização Brasileira, 1968.

FRIEDAN, Betty. A mística feminina. Petrópolis: Editora Vozes limitadas, 1971.

GONZÁLEZ, Lélia. "A categoria político-cultura de Amefricanidade." Revista Tempo Brasileiro. Rio de Janeiro, 92/93; 47/68, jan.-jun., 1988.

LISPECTOR, Clarice. "Amor”. In: Laços de Família. Rio de Janeiro: Rocco, 1998.

LOBATO, Monteiro. Negrinha. Bauru: Edusc, 2000.

LOURO, Guacira Lopes. Sexualidade, gênero e educação. São Paulo: Vozes, 2003.

LUGONES, María. "Colonialidad y género". Tabula Rasa. Bogotá, n. 9, pp. 73-101, juliodiciembre, 2008.

MULHERES DO CINEMA BRASILEIRO. Entrevista, fev. 2005, 8ª Mostra de Cinema de Tiradentes. https://www.mulheresdocinemabrasileiro.com.br/site/entrevistas_depoimentos/visualiza/19 3/Helena-Solberg Acesso: 20.04.2020

PERRONE-MOISES, Leyla. "Paradoxos do nacionalismo literário na América Latina". In: Estudos avançados, 1997, vol. 11, n. 30, pp. 245-259.

TAVARES, Mariana. Helena Solberg: trajetória de uma documentarista brasileira. 2011. Tese. 282 f. (Doutorado em Artes). Programa de Pós-Graduação em Artes da Escola de Belas Artes da Universidade Federal de Minas Gerais, Belo Horizonte, 2011. 


\section{Cracacio \&}

THE DOUBLE day. Direção: Helena Solberg. Estados Unidos, 1975, cor, 53 min.

THE EMERGING Woman. Direção: Helena Solberg. Estados Unidos, 1974, p\&b, 40 min. SIMPLESMENTE Jenny. Direção: Helena Solberg. Estados Unidos, 1977, cor, 32 min.

Recebido em: 22/06/2020

Aceito em: 23/06/2020

Referência eletrônica: SILVA, Meire Oliveira. Mulheres no cinema de Helena Solberg: entre múltiplos olhares e vozes, os documentários A Entrevista (1966) e The Double Day (1975). Criação \& Crítica, n. 29, p., mai. 2021. Disponível em: <http://revistas.usp.br/criacaoecritica>. Acesso em: dd mmm. aaaa. 